Article

\title{
Oxidation of High Yield Strength Metals Tungsten and Rhenium in High-Pressure High-Temperature Experiments of Carbon Dioxide and Carbonates
}

\author{
Raquel Chuliá-Jordán ${ }^{1}$, David Santamaría-Pérez ${ }^{1, *}$, , Tomás Marqueño ${ }^{1}$, Javier Ruiz-Fuertes ${ }^{2}$ \\ and Dominik Daisenberger ${ }^{3}$ \\ 1 Applied Physics Department - ICMUV - MALTA Consolider Team, University of Valencia, c/Dr. Moliner 50, \\ 46100 Burjassot (Valencia), Spain; raquel.chulia@uv.es (R.C.-J.); tomasmarqueno@gmail.com (T.M.) \\ 2 DCITIMAC- MALTA Consolider Team, University of Cantabria, 39005 Santander, Spain; \\ ruizfuertesj@unican.es \\ 3 Diamond Light Source, Didcot, Oxon OX11 0DE, UK; dominik.daisenberger@diamond.ac.uk \\ * Correspondence: david.santamaria@uv.es
}

Received: 24 November 2019; Accepted: 13 December 2019; Published: 17 December 2019

\begin{abstract}
The laser-heating diamond-anvil cell technique enables direct investigations of materials under high pressures and temperatures, usually confining the samples with high yield strength $\mathrm{W}$ and Re gaskets. This work presents experimental data that evidences the chemical reactivity between these refractory metals and $\mathrm{CO}_{2}$ or carbonates at temperatures above $1300{ }^{\circ} \mathrm{C}$ and pressures above $6 \mathrm{GPa}$. Metal oxides and diamond are identified as reaction products. Recommendations to minimize non-desired chemical reactions in high-pressure high-temperature experiments are given.
\end{abstract}

Keywords: reactivity; tungsten; rhenium; carbon dioxide; carbonates; high-pressure high-temperature experiments

\section{Introduction}

Extreme high-pressure high-temperature (HP-HT) conditions are commonly encountered in nature. A primary source for acquiring knowledge of the Earth's interior is, for instance, generating similar pressure and temperature conditions in the laboratory, and studying how these conditions affect metals [1] or minerals [2,3]. A particular interesting problem is to unravel the fate of carbon in the deep mantle [2,4-6], for which HP-HT experiments involving carbon dioxide and carbonates need to be performed. However, the HP-HT chemistry of these compounds is largely unknown, which directly affects the proper design of such experiments.

High-pressure high-temperature physics and chemistry has greatly progressed in the last three decades, thanks to experimental developments. The diamond-anvil cell (DAC), for instance, has made possible to characterize in situ many materials at high pressure via spectroscopic and scattering techniques, due to the fact that diamond is transparent to many forms of electromagnetic radiation (visible, IR, X-ray) [2,7-9]. DACs are based on a simple design that consists of two opposed diamond anvils that compress a thin gasket which holds a tiny sample and a pressure transmitting medium. Experiments at pressures above $30 \mathrm{GPa}$ require hard materials (rhenium, tungsten, diamond powder) with good mechanical properties to be used as gaskets $[10,11]$. Combined high-pressure high-temperature experiments are, however, less common, because they require the simultaneous use of cutting-edge techniques, such as DACs and resistive heaters, or high-power heating lasers, together with complementary characterization techniques [12].

In this context, new advances in static resistive-heated [13] and laser-heated diamond-anvil cells (LHDAC) technology [14], pyrometry and spectroradiometry diagnostic techniques [15], and the 
development of brighter X-ray sources [16] have extended the pressure-temperature regime accessible in HP-HT in situ studies, and allow giving new insights into materials' behavior (reactivity, phase transformations, properties) at these conditions. These experiments try to mimic planets' interiors, and can be therefore considered as windows to observe otherwise inaccessible parts of the Universe.

The thermodynamic stability of $\mathrm{CO}_{2}$ and carbonates at ambient conditions may be significantly altered at high pressures and temperatures in the presence of rhenium or tungsten metal of the gasket. Several studies of the interaction of $\mathrm{CO}_{2}$ with transition metal surfaces at low pressure are available in the literature $[17,18]$. Thus, for example, the overall $\mathrm{CO}_{2}$ dissociative chemisorption on the $\operatorname{Re}(0001)$ surface increases below $140 \mathrm{~K}$ due to long time residence, whereas at higher temperatures, desorption is the dominant process [18]. The kinetics of the oxidation of tungsten by $\mathrm{CO}_{2}$ at $\mathrm{T}>2000{ }^{\circ} \mathrm{C}$ were also reported, and it was pointed out that the reactions of desorbed oxygen became important [19]. The dense $\mathrm{CO}_{2}$ environment in diamond-anvil cell experiments, together with high temperatures, that could help to overcome the barriers to chemically interact with the Re and $\mathrm{W}$ gaskets, may result in undesired reaction products, as reported elsewhere for the case of rhenium [20].

In this work we review previous results on the chemical reactivity of molecular $\mathrm{CO}_{2}$ in the presence of Re metal [21], providing new evidences of diamond formation, and show the occurrence of a redox reaction between tungsten metal and calcium silicate-carbonates under HP-HT conditions. Angle-dispersive powder X-ray diffractometry (XRD) data of in situ and recovered samples in contact with tungsten during compression and laser-heating $(\mathrm{T}>1400 \mathrm{~K})$ show the presence of scheelite-type calcium tungstate (after tilleyite decomposition and carbonate reduction). These results give an overview of the reactivity of these gasket materials at extreme conditions, and emphasize the need of meticulousness while preparing suitable sample chamber configurations to try to avoid non-desired chemical reactions in carbon dioxide and carbonates above that temperature.

\section{Materials and Methods}

High-pressure high-temperature X-ray diffraction (XRD) measurements were performed using symmetric and Boehler-Almax diamond-anvil cells (DACs). The chemical interaction between tungsten and carbonates was observed while laser-heating natural silicate-carbonate samples $[6,22,23]$. Natural tilleyite mineral (specimen YPM MIN 041104, Yale Peabody Museum) from the Crestmore quarry was analyzed by energy-dispersive $\mathrm{X}$-ray spectroscopy, and only traces $(<1 \mathrm{wt} \%)$ of $\mathrm{Al}$ and $\mathrm{K}$ were found apart the $\mathrm{Ca}, \mathrm{Si}, \mathrm{C}$ and $\mathrm{O}$ atoms present in the ideal $\mathrm{Ca}_{5}\left(\mathrm{Si}_{2} \mathrm{O}_{7}\right)\left(\mathrm{CO}_{3}\right)_{2}$ formulae. HP-HT experiments of tilleyite were performed in a DAC with diamonds of $250 \mu \mathrm{m}$ culet diameter, using a $\mathrm{W}$ gasket preindented to a thickness of $35 \mu \mathrm{m}$. A tilleyite sample contained within the $\mathrm{W}$ pressure chamber was heated using a high-power diode-pumped fiber laser with wavelength of $1.07 \mu \mathrm{m}$ and a Cu disk as an internal heater, creating a $30 \mu \mathrm{m}$-diameter stable hotspot comparable in size with the heater. Copper was chosen as this heater material because of its known difficulty in forming carbonates [24] and silicates [25]. In this experiment, the pressure chamber was $\sim 50 \mu \mathrm{m}$ in diameter, and hot $\mathrm{Cu}$ diffused, forming a thin layer that covered the whole pressure chamber. Even though the hotspot was centered, the heat was conducted to the gasket (W)-sample (silicate-carbonate) boundary and a chemical reaction occurred. Here, we report the results of tilleyite compressed to $9 \mathrm{GPa}$, which already converted into post-tilleyite [6], and laser-heated above $1500{ }^{\circ} \mathrm{C}$.

Experimental details of the HP-HT Re $+\mathrm{CO}_{2}$ measurements were already reported elsewhere [21]. In short, rhenium disks of $30 \mu \mathrm{m}$ diameter and 5-12 $\mu \mathrm{m}$ thickness were placed at the center of a $\sim 100 \mu \mathrm{m}$ diameter hole of tungsten gasket. These metallic samples are good absorbers of the infrared radiation of the heating laser described above. High-purity $\mathrm{CO}_{2}$ was loaded in the DAC at room temperature using a gas loading apparatus. $\mathrm{Pure} \mathrm{SiO}_{2}$ was used to thermally isolate the diamond anvils. Two runs were carried out: (1) $8 \mathrm{GPa}-1300{ }^{\circ} \mathrm{C}$ and (2) $24 \mathrm{GPa}-1400{ }^{\circ} \mathrm{C}$. In this experiment, the $\mathrm{W}$ gasket was not in contact to Re heater, and consequently, no $\mathrm{W}$ oxidation was observed.

Pressures were measured before and after heating by the ruby fluorescence method [26]. We also used the equations of state of the metals, $\mathrm{Cu}$ [27] and Re [28], as secondary pressure gauges, with 
a pressure difference with respect to that of the ruby standard of less than $2 \%$. Temperatures were measured fitting the Planck's radiation function to the emission spectra (in the range 550-800 nm) assuming wavelength-independent emissivities [29].

Angle-dispersive $X$-ray diffraction data here presented were collected in two different synchrotron beamlines: GSECARS at the Advanced Photon Source for the $\mathrm{Re}+\mathrm{CO}_{2}$ experiments, and $\mathrm{I} 15$ at the Diamond Light Source for silicate-carbonate heating experiments. At GSECARS, incident X-rays had a wavelength of $0.3344 \AA$ and the beam was focused to $\sim 3 \times 3 \mu \mathrm{m}^{2}$ spot. At the I15 beamline of the Diamond Light Source we used an incident monochromatic wavelength of $0.4246 \AA$ focused to $10 \times 10 \mu \mathrm{m}^{2}$. No rotation of the sample was done during XRD pattern collection. Detectors calibration, correction of distortion and integration to conventional $2 \theta$-intensity data were carried out with the Dioptas software [30]. The indexing and refinement of the powder patterns were performed using the, Unitcell [31], Fullprof [32] and Powdercell [33] program packages.

\section{Results and Discussion}

Suggested gasket materials to reach tens of gigapascals or megabar pressures include high yield strength metals such as rhenium or tungsten.

\subsection{W oxidation}

Oxidation of tungsten produced by different routes has been widely studied in the past [34]. These studies concluded that elevated temperatures would enhance the oxidation rate through the formation of highly volatile tungsten oxides, the oxidation kinetics of this metal being quite complex. For instance, a large number of tungsten oxides and phases have been determined [34]. Tungsten metal, in spite of many attractive properties such as good HT strength and high electrical resistivity, easily oxidizes at ambient pressure.

This low resistance to oxidation was also patent while studying the crystallochemical behavior of natural calcium silicate-carbonate minerals at HP-HT conditions. We heated up the W gasket as described in the "Methods" section, and we characterized the heated area afterwards through XRD mapping. Tilleyite $\mathrm{Ca}_{5}\left(\mathrm{Si}_{2} \mathrm{O}_{7}\right)\left(\mathrm{CO}_{3}\right)_{2}$ was compressed to $9 \mathrm{GPa}$ and laser-heated above $1500{ }^{\circ} \mathrm{C}$, and the XRD patterns of the recovered sample located close to the pressure chamber walls revealed that a chemical reaction had occurred (see Figure 1 and Table 1).

Table 1. List of phases identified at ambient conditions in the recovered sample after compression and laser-heating the silicate-carbonate tilleyite $\mathrm{Ca}_{5}\left(\mathrm{Si}_{2} \mathrm{O}_{7}\right)\left(\mathrm{CO}_{3}\right)_{2}$ in the presence of tungsten.

\begin{tabular}{|c|c|c|}
\hline Compound & Space Group (Nr.) & Lattice Parameters $(\AA)$ \\
\hline Scheelite-CaWO 4 & $I 4_{1} / a(88)$ & $\begin{array}{c}a=5.2404(10) \\
c=11.374(4)\end{array}$ \\
\hline bcc-W & $\operatorname{Im} \overline{3} m(229)$ & $a=3.163(3)$ \\
\hline fcc-Cu & $F m \overline{3} m(225)$ & $a=3.614(3)$ \\
\hline $\begin{array}{c}\text { Quartz-SiO } \\
\text { (distorted) }\end{array}$ & C222 (21) & $\begin{array}{c}a=4.996 \\
b=8.668 \\
c=5.46\end{array}$ \\
\hline $\mathrm{B} 1-\mathrm{CaO}$ & $F m \overline{3} m(225)$ & $\begin{array}{l}a=4.818 \\
a=4.962\end{array}$ \\
\hline Aragonite- $\mathrm{CaCO}_{3}$ & Pmcn (62) & $\begin{array}{l}b=7.969 \\
c=5.743\end{array}$ \\
\hline Diamond -C & $F d \overline{3} m(227)$ & $a=3.567$ \\
\hline
\end{tabular}

Note that the temperature at the reaction's location was not measured, but it must be considerably lower than that at the center of the hotspot [35]. The most intense diffraction peaks correspond to scheelite-type $\mathrm{CaWO}_{4}$, but peaks corresponding to bcc-W (gasket), fcc-Cu (laser absorber), quartz- $\mathrm{SiO}_{2}$ [36], B1-type $\mathrm{CaO}$ and aragonite- $\mathrm{CaCO}_{3}$ are also visible. 
These compounds are compatible with silicate-carbonate decomposition and a subsequent redox reaction involving tungsten and calcium carbonate. Then, the following sequence of reactions:

$$
\begin{gathered}
\text { Decomposition: } \mathrm{Ca}_{5}\left(\mathrm{Si}_{2} \mathrm{O}_{7}\right)\left(\mathrm{CO}_{3}\right)_{2} \rightarrow 2 \cdot \mathrm{CaCO}_{3}+2 \cdot \mathrm{SiO}_{2}+3 \cdot \mathrm{CaO} \\
\text { Redox reaction: } 2 \cdot \mathrm{W}+3 \cdot \mathrm{CaCO}_{3} \rightarrow 2 \cdot \mathrm{CaWO}_{4}+\mathrm{CaO}+3 \cdot \mathrm{C}
\end{gathered}
$$

could eventually give rise to the oxidation of tungsten, from $\mathrm{W}^{0}$ to $\mathrm{W}^{+6}$, and the reduction of carbon, from $\mathrm{C}^{+4}$ to $\mathrm{C}^{0}$. Note, however, that there exists a previous HP-HT study carried out by Liu and Lin [37] where they reported the decomposition of tilleyite at $4 \mathrm{GPa}$ into $\mathrm{CaSiO}$ wollastonite, $\mathrm{Ca}_{2} \mathrm{SiO}_{4}$ larnite and $\mathrm{CaCO}_{3}$ aragonite. Of these phases, only aragonite was found in our recovered sample, and for this reason, this decomposition path was not considered. Figure 1 shows the diffraction image with the trace of diamond formation ((111) reflection), which could not be discerned in the XRD integrated pattern. The chemical reactivity of calcium carbonate under reducing conditions was also reported at $5.5 \mathrm{GPa}$ and $1350^{\circ} \mathrm{C}$ when chemically interacted with iron metal, forming Ca-ferrites and graphite [38]. These redox reactions could take place through a previous decomposition of $\mathrm{CaCO}_{3}$ into $\mathrm{CaO}$ and $\mathrm{CO}_{2}$, or $\mathrm{CaO}, \mathrm{O}_{2}$ and $\mathrm{C}$, but the temperature values cannot be compared, since the latter decomposition was reported to occur at approximately $3200{ }^{\circ} \mathrm{C}$ between 9 and $21 \mathrm{GPa}$ [39]. In fact, Chepurov et al. mentioned that they detected $\mathrm{CaWO}_{4}$ at the contact between $\mathrm{CaCO}_{3}$ and the $\mathrm{W}$-foil used to minimize the contact of Fe with the Pt-ampoule in the multi-anvil HP-HT experiments [38]. It should be also stressed that, in the case at hand, the reaction between tilleyite and tungsten could alternatively occur as a one-step process with $\mathrm{W}$ acting as catalyst.

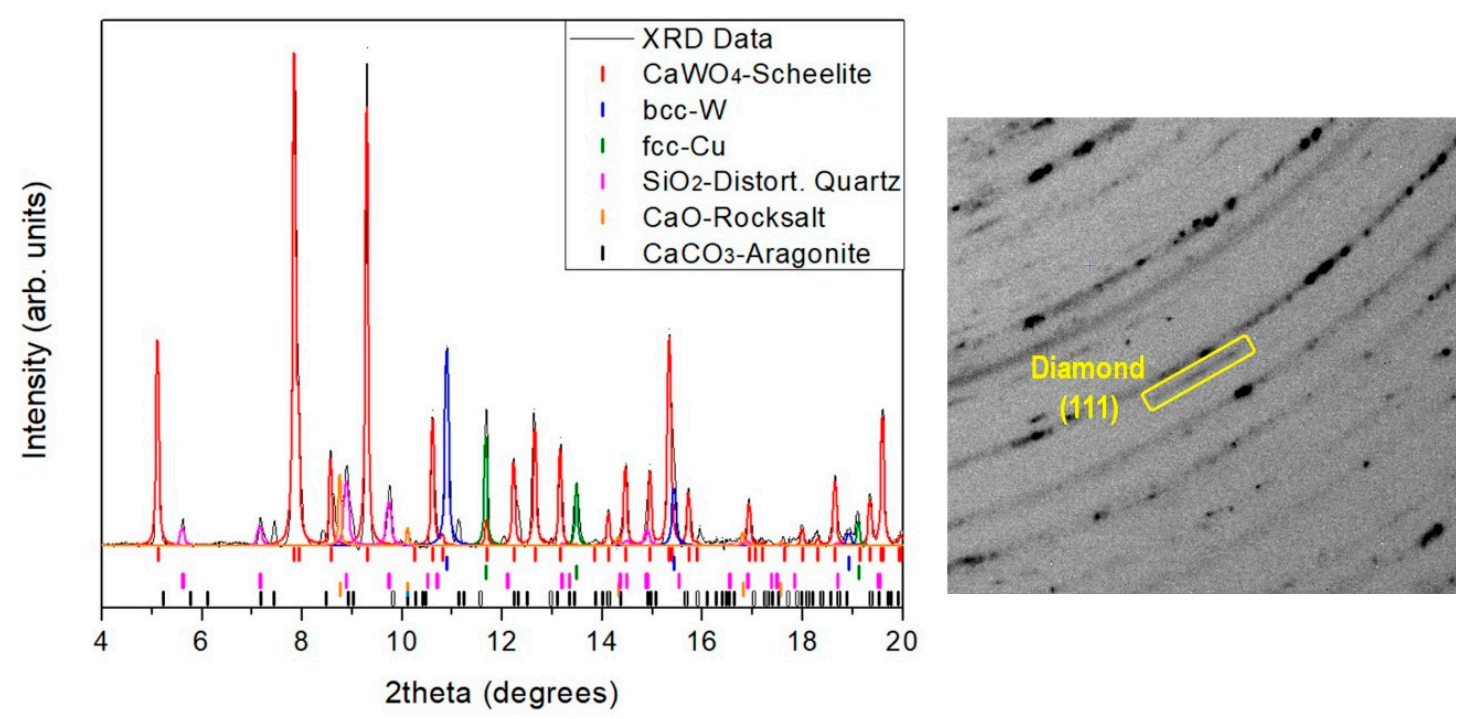

Figure 1. (Right) LeBail fit of the X-Ray diffractometry (XRD) pattern of quenched recovered sample obtained close to the $\mathrm{W}$ gasket after compression $(8 \mathrm{GPa})$ and heating $\left(>1500^{\circ} \mathrm{C}\right)$ of tilleyite. Wavelength: $0.4246 \AA$. Color profiles and vertical marks correspond to the different phases found: scheelite-CaWO $\mathrm{C}_{4}$ (red), bcc-W (blue, gasket), fcc-Cu (green, heater), distorted quartz- $\mathrm{SiO}_{2}$ (magenta), $\mathrm{B} 1-\mathrm{CaO}$ (orange) and aragonite- $\mathrm{CaCO}_{3}$ (black). (Left) Diamond (111) reflection was also found at $2 \theta=11.835^{\circ}$ after inspection of the XRD image.

\subsection{Re Oxidation}

Oxidation of rhenium in oxygen/air occurs above $420{ }^{\circ} \mathrm{C}$ at ambient pressure, and takes place by the formation of volatile oxides, but information available on heterogeneous equilibria in the rhenium-oxygen system is not always consistent. Thus, in a previous work [40], the oxidation reaction has been examined at $427^{\circ} \mathrm{C}$ with $\mathrm{X}$-ray photoelectron and ultra-violet photoelectron spectroscopies. $\mathrm{ReO}_{2}, \mathrm{ReO}_{3}$ and $\mathrm{Re}_{2} \mathrm{O}_{7}$ were found on the Re surface [40]. 
In the temperature range $600-1300{ }^{\circ} \mathrm{C}, \mathrm{Re}_{2} \mathrm{O}_{7}$ was identified by $\mathrm{X}$-ray examination as the only volatile [41] whereas, at higher temperatures $\left(1500-1900{ }^{\circ} \mathrm{C}\right), \mathrm{ReO}_{3}$ was the primary oxide present in the condensed vapor deposits [42]. When mixtures of Re metal and $\mathrm{ReO}_{3}$ in different gross compositions are heated up, a stable intermediary $\mathrm{ReO}_{2}$ phase is formed [43]. However, differences in the thermodynamic characteristics of sublimation, decomposition and disproportionation of these phases are significant [44]. The reasons for literature discrepancies could be the Re surface state and different oxidizing conditions. All in all, like tungsten, rhenium has a limited use as an HT structural material due to its low resistance to oxidation.

At high pressures (from 8 to $25 \mathrm{GPa}$ ), no Re reactivity has been reported with solid or fluid $\mathrm{O}_{2}$ up to $1000{ }^{\circ} \mathrm{C}$ [45]. In the presence of supercritical fluid $\mathrm{H}_{2} \mathrm{O}-\mathrm{O}_{2}$ mixtures, however, Re undergoes a series of reactions to form perrhenic acid $\left(\mathrm{HReO}_{4}\right)$ and its hydrates at pressures as low as $0.5 \mathrm{GPa}$ and at room temperature [46]. From a practical perspective for high pressure research, it is important to know the potential chemical reactivity between the Re gasket and solid and fluid samples. $\mathrm{Re}+\mathrm{CO}_{2}$ interaction at HP and HT was recently studied by our group. Our results demonstrate the existence of carbon dioxide reduction reaction in the presence of Re metal at high pressures ( 8 and $24 \mathrm{GPa}$ ) and high temperatures (above $1200{ }^{\circ} \mathrm{C}$ ), obtaining orthorhombic $\beta-\mathrm{ReO}_{2}$ as high-pressure high-temperature reaction product (see Figure 2 and Table 2).

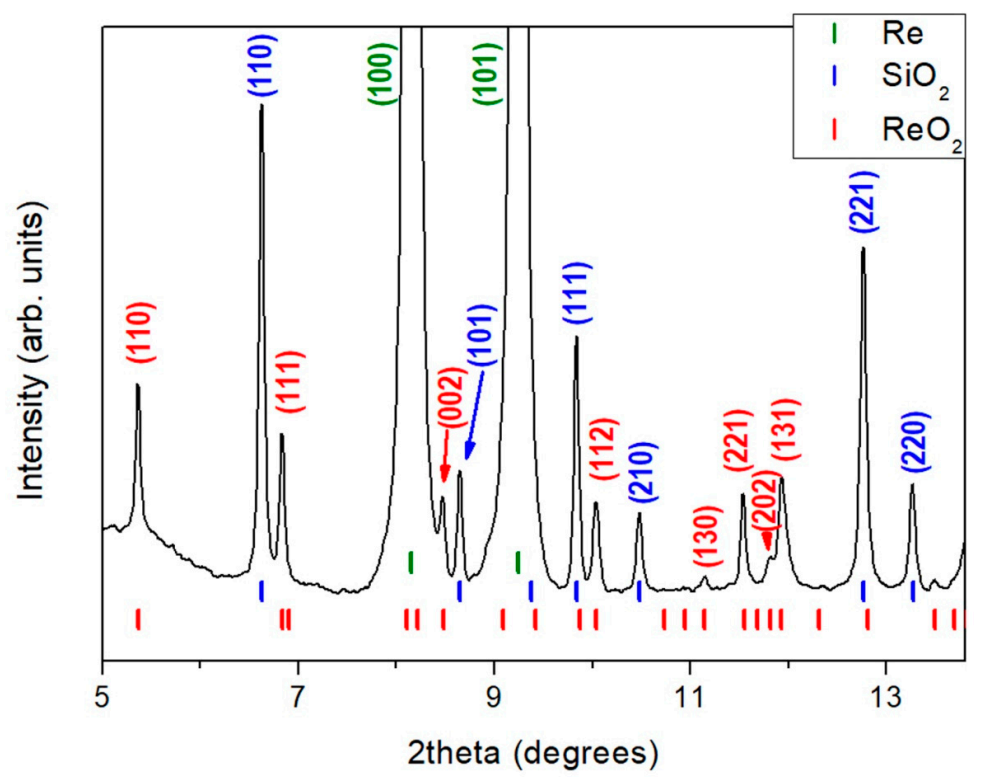

Figure 2. In situ XRD pattern of compressed ( 24 GPa) laser-heated $\left(1300{ }^{\circ} \mathrm{C}\right)$ rhenium in the presence of $\mathrm{CO}_{2}$. Wavelength: $0.3344 \AA$. Silica was used as thermal isolating material. At these P-T conditions, $\mathrm{CO}_{2}$ is liquid and, consequently, no diffraction signal of this phase was observed. Above $1250{ }^{\circ} \mathrm{C}$, the diffraction peaks of orthorhombic $\beta-\mathrm{ReO}_{2}$ were clearly visible. Green, blue and red vertical ticks correspond to hcp- $\mathrm{Re}, \mathrm{SiO}_{2}$-stishovite and $\beta-\mathrm{ReO}_{2}$, respectively.

Table 2. List of phases identified in the in situ XRD pattern of compressed ( 24 GPa) laser-heated $\left(1300{ }^{\circ} \mathrm{C}\right)$ rhenium in the presence of $\mathrm{CO}_{2}$.

\begin{tabular}{|c|c|c|}
\hline Compound & Space Group (Nr.) & Lattice Parameters (̊̊) \\
\hline$\beta-\mathrm{ReO}_{2}$ & Pbcn (60) & $\begin{array}{l}a=4.669(3) \\
b=5.556(3) \\
c=4.524(2)\end{array}$ \\
\hline Stishovite- $\mathrm{SiO}_{2}$ & $\mathrm{P} 4_{2} / \mathrm{mnm}$ (136) & $\begin{array}{c}a=4.0929(11) \\
c=2.639(2)\end{array}$ \\
\hline hcp-Re & $\mathrm{P}_{3} / m m c(194)$ & $\begin{array}{l}a=2.717 \\
c=4.413\end{array}$ \\
\hline
\end{tabular}


This compound, with $\operatorname{Re}(\mathrm{IV})$ oxidation state, is stable and solid at temperatures between 1250 and $1500{ }^{\circ} \mathrm{C}$ while compressed at $24 \mathrm{GPa}$, in comparison to that occurring in vacuum conditions, where $\mathrm{ReO}_{2}$ dissociates at $850-1050{ }^{\circ} \mathrm{C}$ into $\mathrm{Re}_{2} \mathrm{O}_{7}(\mathrm{~g})$ and metallic $\mathrm{Re}[42,47]$.

This rhenium oxide still exists at $50 \mathrm{GPa}$ after heating above $1600{ }^{\circ} \mathrm{C}$ (see Figure 3 and Table 3), together with diamond. In fact, its stability field extends above $1 \mathrm{Mbar}$, as shown in a recent publication [48]. No $\mathrm{Re}_{2} \mathrm{O}_{7}$ or $\mathrm{ReO}_{3}$ were found during our experiments, $\beta-\mathrm{ReO}_{2}$ being recovered after pressure and temperature quenching [21].

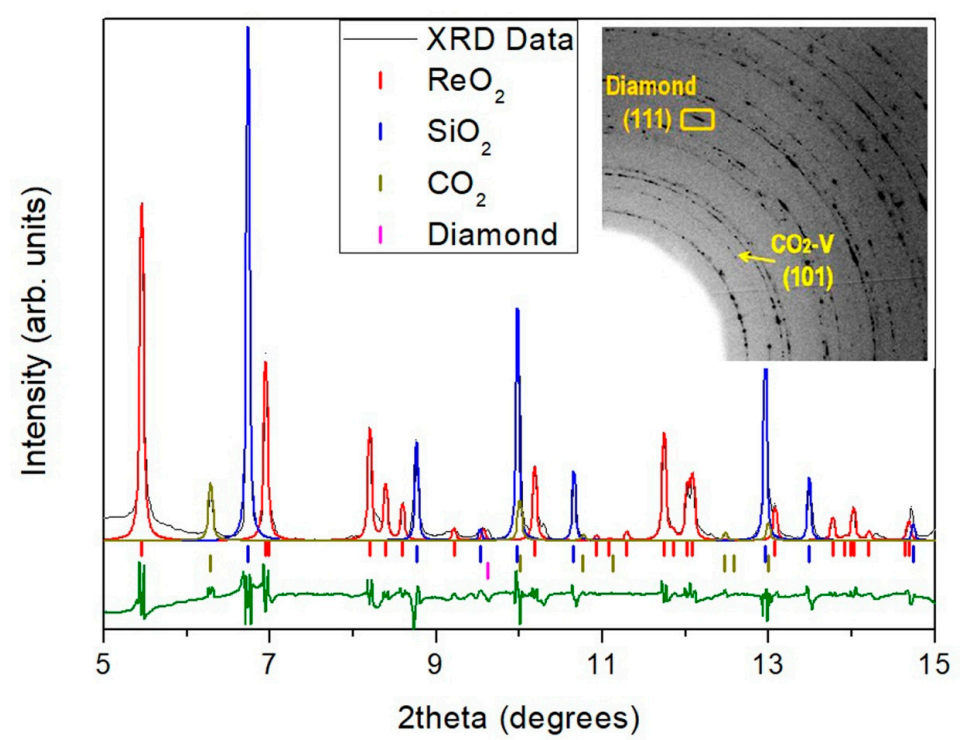

Figure 3. LeBail fit of the in situ XRD pattern of compressed ( $50 \mathrm{GPa})$ laser-heated $\left(1600^{\circ} \mathrm{C}\right)$ rhenium in the presence of $\mathrm{CO}_{2}$. Wavelength: $0.3344 \AA$. Silica was used as thermal isolating material. Experimental data are depicted as a solid black line, and calculated XRD profiles of $\beta-\mathrm{ReO}_{2}, \mathrm{SiO}_{2}$ stishovite, $\mathrm{CO}_{2}-\mathrm{V}$ and diamond are represented as red, blue, dark yellow and magenta lines, respectively. The full difference profile is represented at the bottom as a green line. Inset: XRD image showing the (111) diffraction peak of diamond, after $\mathrm{CO}_{2}$ reduction.

Table 3. List of phases identified in the in situ XRD pattern of compressed ( $50 \mathrm{GPa}$ ) laser-heated $\left(1600{ }^{\circ} \mathrm{C}\right)$ rhenium in the presence of $\mathrm{CO}_{2}$. The lattice parameters of the structures recovered at ambient conditions can be found in Reference. [21].

\begin{tabular}{|c|c|c|}
\hline Compound & Space Group (Nr.) & Lattice parameters $(\AA)$ \\
\hline$\beta-\mathrm{ReO}_{2}$ & Pbcn (60) & $\begin{array}{l}a=4.571(3) \\
b=5.492(2) \\
c=4.462(2)\end{array}$ \\
\hline Stishovite- $\mathrm{SiO}_{2}$ & $\mathrm{P}_{4} / \mathrm{mnm}$ (136) & $\begin{array}{l}a=4.027(2) \\
c=2.607(2)\end{array}$ \\
\hline $\mathrm{CO}_{2}-\mathrm{V}$ & $I \overline{4} 2 d(122)$ & $\begin{array}{l}a=3.563 \\
c=5.905\end{array}$ \\
\hline Diamond -C & $F d-3 m(227)$ & $a=3.453$ \\
\hline
\end{tabular}

From these results, we can infer that the following reaction is taking place: $\mathrm{Re}+\mathrm{CO}_{2} \rightarrow \mathrm{ReO}+$ $\mathrm{C}(\mathrm{d})$. This is in agreement with the observation of (111) reflections of diamond in XRD patterns, as shown in the CCD image depicted in the inset of Figure 3. $\beta-\mathrm{ReO}_{2}$ was quenched both in temperature and in pressure, and recovered at ambient conditions. Thus, the existence of rhenium dioxide through such a wide P-T range illustrates the increasing thermal stability with pressure of this oxidation state IV phase to disproportionation to rhenium metal and higher oxidation state oxides. 


\section{Conclusions}

These results allow drawing an important conclusion: Refractory metals rhenium and tungsten chemically interact with $\mathrm{CO}_{2}$ and carbonates at moderate high temperatures $\left(\mathrm{T}>1300{ }^{\circ} \mathrm{C}\right)$, even at high pressure. These redox reactions give rise to the formation of metal oxide species and diamond. This fact suggests that extreme care should be taken in high-pressure high-temperature experiments involving the aforementioned oxidized carbon species in order to avoid non desired chemical reactions. Our experience suggests following some methodological recommendations to rule out the possibility of chemical interaction in laser-heated diamond-anvil cell experiments:

(i) Center the laser hotspot in the pressure chamber, place it as far as possible from the gasket.

(ii) If heating with a Nd-doped YAG laser, $\lambda=1.06 \mu \mathrm{m}$, do not use Re or $\mathrm{W}$ as an internal absorber of the laser radiation. As seen above, they easily react with the sample above $1300{ }^{\circ} \mathrm{C}$. Pay special attention when using chemically inert $\mathrm{Au}$ as a heater. In the absence of a proper sample containment, this low melting temperature metal [49] would disperse across the pressure chamber and could eventually reach the Re or W gasket. A small and perfectly centered heater foil will minimize this possibility. Something similar occurs with soft $\mathrm{Cu}$ [49] or Pt [50,51].

(iii) A convenient approach is heating the optically transparent samples with a $\mathrm{CO}_{2}$ laser, $\lambda=10.6 \mu \mathrm{m}$. This wavelength equates to a photon energy of the same order of magnitude as lattice phonons in covalent crystals, and it is usually absorbed by minerals and transparent oxides [52]. Note, however, that the focal size of the laser spot in this case is larger than in the case of solid-state lasers [12], making the heating of the gasket metal more likely. Steering and focusing of the beam becomes then critical. The use of gold-coated or diamond gaskets could help in preventing potential metal oxidation products.

From the data obtained, it follows that the decomposition of carbon dioxide and carbonates occurs at relatively low temperatures under reducing conditions, due to chemical interaction with refractory metals.

Author Contributions: Conceptualization, D.S.-P.; laser-heating DAC XRD experiments, D.S.-P., T.M., J.R.-F. and D.D.; Formal analysis, R.C.-J. and D.S.-P.; Writing, R.C.-J. and D.S.-P.; Review, all the authors.

Funding: This work was supported by the Spanish Ministerio de Ciencia, Innovación y Universidades (MICINN) under Grants PGC 2018-097520-A-I00 and RED2018-102612-T (MALTA Consolider), and by the Generalitat Valenciana Grant PROMETEO/2018/123. D. S-P. acknowledges MINECO for a Ramón y Cajal (RyC-2014-15643).

Acknowledgments: Authors thank the APS and Diamond synchrotrons for beamtime allocation at GSECARS and I15 lines and the Mineralogy and Meteoritic Division of the Peaboby Museum for the provision of natural samples.

Conflicts of Interest: The authors declare no conflict of interest.

\section{References}

1. Boehler, R.; Santamaria-Perez, D.; Errandonea, D.; Mezouar, M. Melting, density, and anisotropy of iron at core conditions: New x-ray measurements to 150 GPa. J. Phys. Conf. Ser. 2008, 121, 022018. [CrossRef]

2. Boulard, E.; Pan, D.; Galli, G.; Liu, Z.X.; Mao, W.L. Tetrahedrally coordinated carbonates in Earth's lower mantle. Nat. Commun. 2015, 6, 6311. [CrossRef] [PubMed]

3. Litasov, K.; Othani, E. The solidus of carbonated eclogite in the system $\mathrm{CaO}-\mathrm{Al}_{2} \mathrm{O}_{3}-\mathrm{MgO}-\mathrm{SiO}_{2}-\mathrm{Na}_{2} \mathrm{O}-\mathrm{CO}_{2}$ to $32 \mathrm{GPa}$ and carbonatite liquid in the deep mantle. Earth Planet. Sci. Lett. 2010, 295, 115. [CrossRef]

4. Dasgupta, R. Ingassing, storage, and outgassing of terrestrial carbon through geologic time. Rev. Mineral. Geochem. 2013, 75, 183. [CrossRef]

5. Stagno, V.; Ojwang, D.O.; McCammon, C.A.; Frost, D.J. The oxidation state of the mantle and the extraction of carbon from Earth's interior. Nature 2013, 493, 84. [CrossRef]

6. Santamaria-Perez, D.; Ruiz-Fuertes, J.; Peña-Alvarez, M.; Chulia-Jordan, R.; Marqueño, T.; Zimmer, D.; Gutierrez-Cano, V.; MacLeod, S.; Gregoryanz, E.; Popescu, C.; et al. Post-tilleyite, a dense calcium silicate-carbonate phase. Sci. Rep. 2019, 9, 7898. [CrossRef] 
7. Dunstan, D.J.; Spain, I.L. Technology of diamond anvil high-pressure cell. I. Principles, design and construction. J. Phys. E Sci. Instrum. 1989, 22, 913. [CrossRef]

8. Santamaria-Perez, D.; Kumar, R.S.; Santos-Garcia, A.J.D.; Errandonea, D.; Chulia-Jordan, R.; Saez-Puche, R.; Rodriguez-Hernandez, P.; Muñoz, A. High-pressure transition to the post-barite phase in $\mathrm{BaCrO}_{4}$ hashemite. Phys. Rev. B 2012, 86, 094116. [CrossRef]

9. Aguado, F.; Santamaria-Perez, D. Structure of Earth's interior. In An Introduction to High-Pressure Science and Technology; CRC Press: Boca Raton, FL, USA, 2016.

10. Lavina, B.; Dera, P.; Meng, Y. Synthesis and microdiffraction at extreme pressures and temperatures. J. Vis. Exp. 2013, 80, 50613. [CrossRef]

11. Zou, G.; Ma, Y.; Mao, H.K.; Hemley, R.J.; Gramsch, S.A. A diamond gasket for the laser-heated diamond anvil cell. Rev. Sci. Instrum. 2001, 72, 1298. [CrossRef]

12. Salamat, A.; Fischer, R.A.; Briggs, R.; McMahon, M.I.; Petitgirard, S. In situ synchrotron X-ray diffraction in the laser-heated diamond anvil cell: Melting phenomena and synthesis of new materials. Coord. Chem. Rev. 2014, 278, 15-30. [CrossRef]

13. Santamaria-Perez, D.; Marqueño, T.; MacLeod, S.; Ruiz-Fuertes, J.; Daisenberger, D.; Chulia-Jordan, R.; Errandonea, D.; Jorda, J.L.; Rey, F.; McGuire, C.; et al. Structural evolution of $\mathrm{CO}_{2}$-filled pure silica LTA zeolite under high-pressure high-temperature conditions. Chem. Mater. 2017, 29, 4502-4510. [CrossRef]

14. Boehler, R.; Chopelas, A. A new approach to laser-heating in high-pressure mineral physics. Geophys. Res. Lett. 1991, 18, 1147. [CrossRef]

15. Benedetti, L.R.; Loubeyre, P. Temperature gradients, wavelength-dependent emissivity and accuracy of high temperatures measured in a LHDAC. High Press. Res. 2004, 24, 423-445. [CrossRef]

16. Schultz, E.; Mezouar, M.; Crichton, W.; Bauchau, S.; Blattmann, G.; Andrault, D.; Fiquet, G.; Boehler, R.; Rambert, N.; Sitaud, B.; et al. Double-sided laser heating system for in situ HP-HT monochromatic XRD at the ESRF. High Press. Res. 2005, 25, 71-83. [CrossRef]

17. Freund, H.J.; Roberts, M.W. Surface chemistry of carbon dioxide. Surf. Sci. Rep. 1996, 25, 225-273. [CrossRef]

18. Peled, H.; Asscher, M. Dissociative chemisorption of $\mathrm{CO}_{2}$ on $\operatorname{Re}(0001)$ single crystal surface. Surf. Sci. 1987, 183, 201-215. [CrossRef]

19. Walsh, P.N.; Quets, J.M.; Graff, R.A.; Ladd, I.R. Kinetics of the oxidation of tungsten by $\mathrm{CO}_{2}$ at high temperatures. J. Chem. Phys. 1967, 46, 3571-3576. [CrossRef]

20. Santamaria-Perez, D.; McGuire, C.; Mahkluf, A.; Kavner, A.; Chulia-Jordan, R.; Rey, F.; Pellicer-Porres, J.; Martinez-Garcia, D.; Rodriguez-Hernandez, P.; Muñoz, A. Strongly-driven $\mathrm{Re}+\mathrm{CO}_{2}$ redox reaction at high-pressure and high-temperature. Nat. Commun. 2016, 7, 13647. [CrossRef]

21. Santamaria-Perez, D.; McGuire, C.; Kavner, A.; Chulia-Jordan, R.; Pellicer-Porres, J.; Martinez-Garcia, D.; Doran, A.; Kunz, M.; Rodriguez-Hernandez, P.; Muñoz, A. Exploring the chemical reactivity between carbon dioxide and three transition metals $(\mathrm{Au}, \mathrm{Pt}$, and $\mathrm{Re})$ at high pressures and temperatures. Inorg. Chem. 2016, 55, 10793. [CrossRef]

22. Grice, J.D. The structure of spurrite, tileyite and scawtite, and relationships to other silicate-carbonate minerals. Can. Mineral. 2005, 43, 1489-1500. [CrossRef]

23. Santamaria-Perez, D.; Ruiz-Fuertes, J.; Marqueño, T.; Pellicer-Porres, J.; Chulia-Jordan, R.; MacLeod, S.; Popescu, C. Structural behavior of natural silicate-carbonate spurrite mineral, $\mathrm{Ca}_{5}\left(\mathrm{SiO}_{4}\right)_{2}\left(\mathrm{CO}_{3}\right)$, under high-pressure high-temperature conditions. Inorg. Chem. 2018, 57, 98-105. [CrossRef] [PubMed]

24. Isaacs, T. The mineralogy and chemistry of nickel carbonates. Mineral. Mag. 1963, 33, 663-678. [CrossRef]

25. Otto, H.H.; Meibohn, M. Crystal structure of copper polysilicate, $\mathrm{Cu}_{[}\left[\mathrm{SiO}_{3}\right]$. Z. Kristallogr. 1999, 214, 558-565. [CrossRef]

26. Mao, K.K.; Xu, J.; Bell, P.M. Calibration of the Ruby Pressure Gauge to 800-Kbar under Quasi-Hydrostatic Conditions. J. Geophys. Res. 1986, 91, 4673-4676. [CrossRef]

27. Dewaele, A.; Loubeyre, P.; Mezouar, M. Equations of state of six metals above 94 GPa. Phys. Rev. B 2004, 70, 094112. [CrossRef]

28. Jeanloz, R.; Godwal, B.K.; Meade, C. Static Strength and Equation of State of Rhenium at Ultra-High Pressures. Nature 1991, 349, 687-689. [CrossRef]

29. Santamaria-Perez, D.; Ross, M.; Errandonea, D.; Mukherjee, G.D.; Mezouar, M.; Boehler, R. X-ray diffraction measurements of Mo melting to $119 \mathrm{GPa}$ and the high pressure phase diagram. J. Chem. Phys. 2009, 130, 124509. [CrossRef] 
30. Prescher, C.; Prakapenka, V.B. DIOPTAS: A Program for Reduction of Two-Dimensional X-Ray Diffraction Data and Data Exploration. High Press. Res. 2015, 35, 223-230. [CrossRef]

31. Holland, T.J.B.; Redfern, S.A.T. Unit cell refinement from powder diffraction data: The use of regression diagnostics. Mineral. Mag. 1997, 61, 65-77. [CrossRef]

32. Rodriguez-Carvajal, J. Recent Advances in Magnetic-Structure Determination by Neutron Powder Diffraction. Phys. B 1993, 192, 55-69. [CrossRef]

33. Nolze, G.; Kraus, W. Powdercell 2.0 for Windows. Powder Diffr. 1998, 13, 256-259.

34. Ivanov, V.Y.; Nechiporenko, Y.P.; Yefimenko, L.N.; Yurchenko, M.I. High Temperature Oxidation Protection of Tungsten; NASA Translation of "Zashchita Vol'frama ot Okisleniya pri Vysokikh Temperaturakh" Atom Press: Moscow, Russia, 1968.

35. Boehler, R. High-pressure experiments and phase diagram of lower mantle and core materials. Rev. Geophys. 2000, 38, 221-245. [CrossRef]

36. Marqueño, T.; Santamaria-Perez, D.; Ruiz-Fuertes, J.; Chulia-Jordan, R.; Jorda, J.L.; Rey, F.; McGuire, C.; Kavner, A.; MacLeod, S.; Daisenberger, D.; et al. An ultrahigh $\mathrm{CO}_{2}$-loaded silicalite zeolite: Structural stability and physical properties at high pressures and temperaturas. Inorg. Chem. 2018, 57, 6447-6455. [CrossRef]

37. Liu, L.G.; Lin, C.C. High-pressure phase transformations of carbonates in the system $\mathrm{CaO}-\mathrm{MgO}-\mathrm{SiO}_{2}-\mathrm{CO}_{2}$. Earth Planet. Sci. Lett. 1995, 134, 297-305. [CrossRef]

38. Chepurov, A.I.; Sonin, V.M.; Zhimulev, E.I.; Chepurov, A.A.; Tomilenko, A.A. On the formation of element carbon during decomposition of $\mathrm{CaCO}_{3}$ at high P-T parameters under reducing conditions. Dokl. Earth Sci. 2011, 441, 1738-1741. [CrossRef]

39. Bayarjargal, L.; Shumilova, T.G.; Friedrich, A.; Winkler, B. Diamond formation from $\mathrm{CaCO}_{3}$ at high pressure and temperature. Eur. J. Mineral. 2010, 22, 29-34. [CrossRef]

40. Alnot, M.; Ehrhardt, J. A study of oxygen-rhenium interactions in various pressure and temperature conditions. J. Chim. Phys. 1982, 79, 735-739. [CrossRef]

41. Phillips, W.L., Jr. The rate of oxidation of rhenium at elevated temperatures in air. J. Less Common Met. 1963, 5, 97-100. [CrossRef]

42. Chou, T.C.; Joshi, A.; Packer, C.M. Oxidation behavior of rhenium at high temperatures. Scr. Metall. Mater. 1993, 28, 1565-1570. [CrossRef]

43. Magneli, A. Studies on rhenium oxides. Acta Scand. 1957, 11, 28-33. [CrossRef]

44. Shcheglov, P.A.; Drobot, D.V. Heterogeneous equilibria in the rhenium-oxygen system. Russ. J. Phys. Chem. 2006, 80, 1819-1825. [CrossRef]

45. Santoro, M.; Gregoryanz, E.; Mao, H.K.; Hemley, R.J. New phase diagram of oxygen at high pressures and temperatures. Phys. Rev. Lett. 2004, 93, 265701-265704. [CrossRef] [PubMed]

46. Chellappa, R.S.; Somayazulu, M.; Hemley, R.J. Rhenium reactivity in $\mathrm{H}_{2} \mathrm{O}-\mathrm{O}_{2}$ supercritical mixtures at high pressures. High Press. Res. 2009, 29, 792-799. [CrossRef]

47. Haynes, W.M. Physical Constants of Inorganic Compounds in CRC Handbook of Chemistry and Physics, 97th ed.; CRC Press: Boca Raton, FL, USA, 2016.

48. Dziubek, K.F.; Ende, M.; Scelta, D.; Bini, R.; Mezouar, M.; Garbarino, G.; Miletich, R. Crystalline polymeric carbón dioxide stable at megabar pressures. Nat. Commun. 2018, 9, 3148. [CrossRef]

49. Hieu, H.K.; Ha, N.N. High pressure melting curves of silver, gold and copper. AIP Adv. 2013, 3, 112125. [CrossRef]

50. Kavner, A.; Jeanloz, R. High-pressure melting curve of platinum. J. Appl. Phys. 1998, 83, 7553-7559. [CrossRef]

51. Anzellini, S.; Monteseguro, V.; Bandiello, E.; Dewaele, A.; Burakovsky, L.; Errandonea, D. In situ characterization of the high pressure-High temperature melting curve of platinum. Sci. Rep. 2019, 9, 13034. [CrossRef]

52. Smith, D.; Smith, J.S.; Childs, C.; Rod, E.; Hrubiak, R.; Shen, G.; Salamat, A. A CO 2 laser heating system for in situ high pressure-temperature experiments at HPCAT. Rev. Sci. Instrum. 2018, 89, 083901. [CrossRef]

(C) 2019 by the authors. Licensee MDPI, Basel, Switzerland. This article is an open access article distributed under the terms and conditions of the Creative Commons Attribution (CC BY) license (http://creativecommons.org/licenses/by/4.0/). 